\title{
Identitas Politik dalam Komunikasi Politik Calon Gubernur Jawa Barat Tahun 2018
}

\author{
Adiyana Slamet \\ Universitas Komputer Indonesia \\ e-mail: Adivana.slamet@email.unikom.ac.id
}

\begin{abstract}
ABSTRAK
Penggunaan politik identitas dalam Komunikasi politik calon Gubernur Jawa Barat 2018, dijadikan salah satu faktor penting dalam merebut hati pemilih. Tiga dari empat calon Gubernur dan Wakilnya, berkontestasi dengan memunculkan identitas politik kedaerahan, Sunda, dan satu kandidat, lebih memunculkan identitas politik Agama, dalam hal ini Islam. Empat pasang bakal kandidat yang maju dalam pemilihan Gubernur Jawa Barat tersebut antara lain: Deddy Mizwar, Ridwan Kamil, Sudrajat, dan Tubagus Hasanuddin. Para kandidat perlu meyakinkan hati pemilih di 27 Kabupaten/Kota yang ada di Jawa Barat, dengan jumlah daftar pemilih tetap 32.809.057 suara. Sebagaimana yang tertuang dalam visi misi calon Gubernur dan Wakil Gubernur dan retorika Kampanye, identitas budaya sunda sebagai symbol politik pakaian menjadi kuat, ini tercermin pada saat pelaksanaan debat pertama yang diselenggarakan oleh KPU Jawa Barat Pada 27 Juni 2018. Penelitian ini menggunakan pendekatan kualitatif dengan desain studi kasus. Penggunaan identitas politik dalam komunikasi politik calon Gubernur Jawa Barat. Ada beberapa temuan, antara lain pertama, pentingnya identitas politik untuk meyakinkan pemilih dalam kontestasi pemilihan Gubernur Jawa Barat tahun 2018, kedua, identitas politik yang digunakan melalui simbol-simbol politik dangan retorika verbal dalam menghadapi konstituen baik secara langsung maupun di media lama maupun baru, ketiga penggunaan identitas politik melalui simbol non verbal, seperti baju dan ikat kepala yang kemudian menjadi kehasan dari calon, dan ke empat, identitas politik dilakukan dengan memunculkan simbol-simbol agama, seperti yang digunakan oleh pasangan Asyik dan Pasangan Deddy Mizwar.
\end{abstract}

Kata Kunci : Identitas Politik, Komunikasi Politik, Pemilihan Gubernur Jawa Barat Tahun 2018 


\section{Pendahuluan}

Komunikasi politik yang dilakukan Calon Gubernur Jawa Barat pada pemilihan kepala daerah serentak tahun 2018 dengan memunculkan identitas politik Sunda sangat strategis untuk meyakinkan hati pemilih di Jawa Barat yang secara etnofilosofis beretnis Sunda, hal tersebut sejalan dengan perspektif political symbolism (Cohen, 1947, dalam Lewellen, 1982:110) atau persepektif interaksi simbolik dalam konteks politik. Hal ini didasrakan atas asumsi bahwa "pembicaraan politik adalah aktivitas simbolik" (Nimmo, 2006:79). Maka, transaksi politik, simbolisme dalam politik menjadi penting dalam komunikasi politik.

Komunikasi politik simbolisme menjadi unsur yang penting dalam merebut hati pemilih pada segnetasi antropologis, yang kemudian diindentifikasi memilih berdasarkan kedekatan budaya. Dalam komunikasi Politik didalamnya dikenal dua macam simbol, yakni concrete and abstract symbol (White \& Clark, 1988:8). Simbolsimbol kongkrit mengacu pada objek atau sumber daya yang berwujud (tangible resources). Simbol seperti ini dapat diobservasi secara langsung. Sedangkan simbol yang abstrak mengacu pada sumber daya yang tidak terwujud (intangible resources) nilai-nilai sosial tertentu. Bentuk yang spesifik, simbolisasi dalam komunikasi politik akan tampak dalam alat-alat retorika yang digunakan, seperti metafora.

Hiruk pikuk jelang perhelatan pesta demokrasi 5 tahunan sekali, menurut Kumolo.( 2017:79), Pilkada kini lebih menarik dibincangkan banyak orang, khususnya sejak diselenggarakan secara langsung. Perbincangan yang dimaksud adalah tentang hal ihwal calon kepala daerah dan wakilnya. Lebih jauh, sinyalemen sementara, masyarakat mulai meyakini hubungan kepemimpinan daerah terhadap perikehidupan mereka sendiri dari kepala daerah yang dipilih. Ini mengiindikasikan, di satu sisi, dinamika demokrasi lokal memberi sinyal positif bahwa masyarakat makin dewassa berpolitik walaupun yang menjadi perhatian dalam sejarahnya adalah janji atau program-program calon kepala daerah dan wakil kepala daerah.

Realitas yang terjadi pada Pemilian Gubernur di Jawa Barat tahun 2018 misalnya, calon-calon Gubernur dan Wakil Gubernur yang berkontestasi tiga dari empat kandidat Gubernur dan Wakil Gubernur memunculkan identitas politik Sunda dan Agama, dalam hal ini Islam dalam meyakinkan hati pemilih di 27 Kabupaten/Kota di Jawa Barat, yang tertuang dalam retorika Kampanye, dan 
dimasukan kedalam visi misi calon Gubernur dan Wakil Gubernur, dan symbolsimbol pakaian yang merupakan khas identitas Budaya Suda, terlebih lagi saat debat pertama yang diselenggarakan oleh KPU Jawa Barat. Empat pasang bakal kandidat yang maju dalam pemilihan Gubernur Jawa Barat pada tahun 2018. Mereka adalah Deddy Mizwar, Ridwan Kamil, Sudrajat, dan Tubagus Hasanuddin. Pada 27 Juni 2018, mereka akan memperebutkan daftar pemilih tetap 32.809.057 suara pemilih di Jawa Barat. Deddy Mizwar, yang berpasangan dengan Dedi Mulyadi, diusung Partai Golongan Karya dan Partai Demokrat. Pasangan Ridwan Kamil-Uu Ruzhanul Ulum diusung PPP, PKB, NasDem, dan Hanura. Duet Sudrajat-Ahmad Syaikhu diusung Gerindra, PKS, dan PAN. Adapun Tubagus Hasanuddin, yang berpasangan dengan Anton Charliyan, diusung oleh PDI Perjuangan.

Dinamika politik lokal dengan memunculkan identitas politik dalam komunikasi politik untuk merebut hati pemilih menjadi hal yang sentral dalam ruang Jawa Barat. Identitas politik bagi aktor politik dirasa memiliki peran yang sangat penting bagi pembentukan citra aktor politik. Identitas Politik yang dilakukan oleh aktor politik (Gubernur/wakil Gubernur) bisa bermacam-macam. Mulai dari berbentuk verbal maupun non verbal. Melalui komunikasi verbal (verbal communication). Dari penjelasan penelitian ini, maka untuk memformulakan penelitian ini, maka permasalahan yang diteliti, Bagaimana komunikasi politik Calon Gubernur dan Wakil Gubernur Provinsi Jawa Barat dalam memunculkan identitas politik dalam Pemilihan Gubernur Jawa Barat tahun 2018?

Kraus dan davis (Arifin, 2011:13) menyampaikan pendapatnya tentang pengertian komunikasi politik yakni komunikasi politik dilukiskan sebagai proses komunikasi massa dan elemen-elemen di dalamnya yang mungkin mempunyai dampak terhadap perilaku politik. Meadow (Arifin, 2011:16) menyampaikan bahwa komunikasi politik meliputi sebagai bentuk pertukaran simbol atau pesan yang sampai tingkat tertentu dipengaruhi atau mempengaruhi berfungsinya sistem politik.

Pendapat berbeda disampaikan Nimmo (dalam Muhtadi, 2008:21) mengenai keterlibatan politik seorang kandidat atau sekelompok orang dalam komunikasi politik sebagai berikut :

"Keterbukaan kepada komunikasi politik dapat mempengaruhi orang untuk secara 
aktif terlibat dalam politik disatu pihak, dan dipihak lain, komunikasi politik juga bisa menekan partisipasi politik, karena itu, manuver-manuver politik yang sering keluar dari sejumlah elit dan aktor politik pada umumnya, pada gilirannya dapat berimplikasi pada pembentukan perilaku individu dan kelompok yang terlibat dalam proses tersebut. Pesan-pesannya akan menjadi rujukan penting dalam mengambil tindakan-tindakan formal ataupun informal khususnya berkenaan dengan aktivitas politik.". Sementara jika komunikasi politik dilihat dari segi proses sebagaimana disampaikan oleh McQuil (Pawito, 2009:2) adalah sebagai berikut : "All processes of information (including fact, opinion, beliefs, etc) transmission, exchange, and search engaged in the course of institutionalized political activities" atau dapat dikatakan bahwa semua proses penyampaian informasi termasuk fakta, pendapat-pendapat, keyakinan-keyakinan, dan seterusnya, pertukaran dan pencarian tentang itu semua yang dilakukan oleh partisipan dalam konteks kegiatan politik yang bersifat melembaga.

Identitas politik (political identity) secara konseptual berbeda dengan "politik identitas" (political of identity). Identitas politik merupakan konstruksi yang menentukan posisi kepentingan subjek di dalam suatu ikatan komunitas politik, sedangkan pengertian politik identitas mengacu pada mekanisme politik pengorganisasian identitas (baik identitas politik maupun identitas sosial) sebagai sumberdaya dan sarana politik (Setyaningrum, 2005: 19).

Secara sederhana, apa yang dimaksud identitas didefinisikan sebagai karakteristik esensial yang menjadi basis pengenalan dari sesuatu hal. Identitas merupakan karakteristik khusus setiap orang atau komunitas yang menjadi titik masuk bagi orang lain atau komunitas lain untuk mengenalkan mereka (Widayanti, 2009: 13). Menurut Stuart Hall, identitas seseorang tidak dapat dilepaskan dari "sense (rasa/kesadaran) terhadap ikatan kolektivitas". Dari pernyataan tersebut, maka ketika identitas diformulasikan sebagai sesuatu yang membuat seseorang memiliki berbagai persamaan dengan orang lain, maka pada saat yang bersamaan juga identitas memformulasikan otherness (keberbedaan) atau sesuatu yang diluar persamaan-persamaan tersebut. Sehingga karakteristik identitas bukan hanya dibentuk oleh ikatan kolektif, melainkan juga oleh kategori-kategori pembeda (categories of difference) (Setyaningrum, 2005:26). 
Identitas selalu melekat pada setiap individu dan komunitas. Identitas merupakan karekteristik yang membedakan antara orang yang satu dengan orang yang lain supaya orang tersebut dapat dibedakan dengan yang lain. Identitas adalah pembeda antara suatu komunitas dengan komunitas lain. Identitas mencitrakan kepribadian seseorang, serta bisa menentukan posisi seseorang. Ada 3 pendekatan pembentukan identitas, yaitu:

1. Primodialisme. Identitas diperoleh secara alamiah, turun temurun.

2. Konstruktivisme. Identitas sebagai sesuatu yang dibentuk dan hasil dari proses sosial yang kompleks. Identitas dapat terbentuk melalui ikatan- ikatan kultural dalam masyarakat.

3. Instrumentalisme. Identitas merupakan sesuatu yang dikonstruksikan untuk kepentingan elit dan lebih menekankan pada aspek kekuasaan. (Widayanti, 2009: 1415)

\section{Metode Penelitian}


Pendekatan kasus yang diamati yakni Identitas Politik dalam komunikasi politik yang dilakukan Calon Gubernur dan Wakil Gubernur Provinsi Jawa Barat tahun 2018. Dalam penelitian ini peneliti berusaha untuk mengamati, memahami dan menganalisis komunikasi politik Calon Gubernur dan Wakil Gubernur Provinsi Jawa Barat dalam memunculkan identitas politik dalam Pemilihan Gubernur Jawa Barat tahun 2018. Salah satu karakter penelitian kualitatif adalah melakukan pengamatan dan berinteraksi dengan subyek penelitian untuk berusaha memahami bahasa dan tafsiran mereka atas dunianya.

Dalam penelitian ini, peneliti menentukan informan dengan menggunakan teknik purposive sampling, dimana teknik ini mencakup orang-orang yang diseleksi atas dasar kriteria-kriteria tertentu yang dibuat peneliti berdasarkan tujuan penelitian. (Kriyantono, 2007:154)

Menurut Creswell kriteria informan yang baik adalah: "all individuals studied represent people who have experienced the phenomenon" (Creswell, 1998: 118). Jadi, lebih tepat memilih informan yang benarbenar memiliki kapabilitas karena pengalamannya dan mampu mengartikulasikan pengalaman dan pandangannya tentang sesuatu yang dipertanyakan.

Adapun yang menjadi informan dalam penelitian ini adalah, sebagai berikut :Abdy Yuhana Ketua Tim sukses pasangan Hasanudin dan Anton Carlian (Hasanah) pada pemilihan Gubernur Jawa Barat Periode 2018, Dedy Mizwar adalah Calon Gubernur yang berpasangan dengan dedi Mulyadi, dan Muradi, merupakan Pakar Politik.

\section{Tabel 1 Daftar Informan Penelitian}

\begin{tabular}{|c|c|c|}
\hline No & Nama & Keterangan \\
\hline 1 & $\begin{array}{l}\text { H. Deddy } \\
\text { Mizwar, M.IP }\end{array}$ & $\begin{array}{l}\text { Calon Gubernur } \\
\text { Jawa Barat } 2018\end{array}$ \\
\hline 2 & $\begin{array}{ll}\text { Dr. } & \text { Abdy } \\
\text { Yuhana, } & \text { SH., } \\
\text { MH } & \end{array}$ & $\begin{array}{l}\text { Ketua Tim } \\
\text { Pemenangan calon } \\
\text { Gubernur Jawa } \\
\text { Barat } 2018 \text { TB. } \\
\text { Hassanudin-Anton } \\
\text { Charlyan }\end{array}$ \\
\hline 3 & Muradi, Ph.D & Pakar Politik \\
\hline
\end{tabular}


Dalam penentuan informan yang diuraikan diatas tentu tidak mungkin tanpa adanya alasan dan pertimbangan tertentu, peneliti memilih informan memang merupakan orang yang kompeten dan yang dianggap peneliti memiliki pengetahuan tentang masalah yang diteliti. Teknik pengumpulan data Data dalam penelitian ini bersumber dari data primer dan data sekunder. Data primer bersumber dari informasi yang diberikan oleh para informan sebagai subjek penelitian melalui wawancara mendalam. Selain itu juga bersumber dari observasi atau serangkaian pengamatan yang dilakukan oleh peneliti mengenai identitas Komunikasi politik Calon Gubernur Jawa Barat tahun 2018. Data sekunder adalah data yang diperoleh dari berbagai sumber yang berhubungan dengan hal-hal yang diteliti berupa buku, majalah, surat kabar, jurnal, disertasi, kliping, serta literatur-literatur lainnya yang berkaitan dengan masalah penelitian.

Menurut peneliti prosedur pengumpulan data secara langsung dengan melakukan wawancara, observasi sebagai data primer dalam penelitian kualitatif sebagai konsekwensi yang peneliti harus ambil untuk menggali data dan infromasi pada subjek penelitian agar mendapatkan data titik jenuh disamping data sekunder yang peneliti dapat melalui pengumpulan dokumen dan perekaman audio visual dilapangan, serta peneliti juga memilih Pengumpulan data dilakukan secara langsung melalui proses wawancara dengan informan, mengamati perilaku mereka, juga didukung oleh data sekunder berupa literature dan sumber data penunjang, dimana satu sama lain saling menunjang dan melengkapi.

Selain itu, aktivitas pengumpulan data yang peneliti lakukan mengacu pada aktivitas pengumpulan data dari Creswell yaitu “A Data Collection Circle” (Creswell, 1998:109-135). Aktivitas yang dilakukan dengan model Creswell memperlihatkan bahwa satu sama lain saling berhubungan, diawali dengan penentuan tempat atau individu. Pada model " A Data Collecting Circle" dari Creswell, proses pendekatan ini disebut sebagai "Gaining Access and Making Repport" atau proses pendekatan.

Uji keabsahan data dalam penelitian kualitatif meliputi beberapa pengujian. Uji keabsahan data ini diperlukan untuk menentukan valid atau tidaknya suatu temuan atau data yang dilaporkan peneliti dengan apa yang terjadi sesungguhnya di lapangan. Berikut adalah teknik pemeriksaan keabsahan data penelitian yang 
dikemukakan oleh Moleong (2005:327-339) sebagai berikut.

1. Triangulasi, teknik pemeriksaan keabsahan data yang memanfaatkan sesuatu yang lain.

2. Pemeriksaan anggota, yaitu peneliti mengumpulkan pandangan dari para partisipan tentang kredibilitas dari temuan dan penafsirannya.

(Creswell, 2014:350)

Teknik analisis data yang peneliti pakai dalam penelitian ini ialah analisis data kualitatif. Menurut Miles dan Huberman (1984) menjelaskan bahwa analisis data terdiri dari :

1. Pengumpulan Data (Data Collection)

2. Reduksi Data (Data Reduction)

3. Penyajian Data (Data display)

4. Penarikan kesimpulan atau tahap verifikasi (Conclusing drawing \& verification)

\section{Hasil dan Diskusi}

Kontestasi pemilihan Gubernur Jawa

Barat 2018 seharusnya menjadi sebuah ajang bagaimana bakal calon (balon) memiliki nilai lebih, atas visi-misi, program ataupun gagasan yang akan diusung untuk 5 tahun kedepan dalam membangun Jawa Barat. Kita tidak bisa menaifkan bahwa Jawa Barat punya ke-khasan. Setidaknya dari sisi demografis, geografis, ekonomi, pendidikan. Jawa barat mempunyai letak strategis dekat dengan pusat pemerintahan, penduduknya masih menjadi DPT (Daftar Pemilih Tetap) terbesar yang berjumlah 32.809.057, menjadi penyangga ibu kota, masyarakatnya beragam secara historis mempunyai kekayaan yang luar biasa. Esensinya siapapun aktor politik yang mengikuti kontestasi pemilihan Gubernur Jawa Barat tahun 2018 tidak bisa melepaskan diri dari konteks identitas politik untuk merebut hati pemilih.

Seperti wawancara dengan informan Abdy Yuhana, sebagai Ketua Tim Sukses Pemenangan Pasangan Hasanudin -Anton Charlian (Hasanah) mengatakan bahwa, "Identitas politik itu sangat penting, karena identitas politik itu di Jawa Barat pasti mengacu pada identitas budaya Sunda, itu dia akan melekat pada Pak Hasan dan masyarakat Jawa Barat. Karena kan Pak Hasan itu kan orang Majalengka yang kental dengan Budaya sundanya, dan itu termanifestasi dalam kehidupan masyarakat sehari-hari. Kan gak mungkin Pak Hasan itu tidak menonjolkan bahasa Sunda,untuk meyakinkan pemilih, dan Pasangan Hasanah Visi Misinya pun memakai Bahasa Sunda, seperti program molotot.com, Jabar Seubeuh, Turkamling, hingga Imah 
Rempeug, dan itu semua kita yakini sebagai penghargaan untuk entitas Sunda ." (Wawancara, 17 Mei 2018)

Alih-alih pemilihan kepala daerah (Pilkada) merupakan hajat demokrasi dimana rakyat sebagai pemilik kedaulatan untuk memilih pemimpin daerahnya secara langsung, yang smenjadi ajang bagi para bakal calon untuk menawarkan ide, visi misi, program ataupun gagasan untuk bisa mensejahterakan warganya dengan prospective policy choice namun harus bersentuhan dengan kearifan lokal sebagai menarik simpatik pemilih sehingga Calon Gubernur tersebut bisa memenangi kontestasi dalam Pemilihan Gubernur Jawa Barat tahun 2018.

Pentingnya identitas politik dikatakan Informan Muradi, P.hD sebagai pakar politik mengatakan bahwa : "Katakanlah begini identitas politik adalah basis awal seseorang untuk bisa menjadikan dirinya menjadi bagian dari komunitas politik, dalam hal Pemilihan Gubernur Jawa Barat, identitas politik yang menonjol dalah Budaya Sunda dan Agama, tentunya Islam, sehingga calon Gubernur akan mengeksploitasi dua hal tersebut dalam melakukan pendekatan pada pemilih pada Pemilihan Gubernur mendatang itu dasarnya identitas politik." (Wawancaraa, 14 Mei 2018)

Identitas politik juga terkadang dijadikan alat sebagai symbol politik yang hanya untuk merebut hati publik dalam komunikasi politik calon Gubernur, seperti penelitian Adiyana Slamet dalam Prosiding Internasional, hasil penelitian tersebut menemukan beberapa prinsip yaitu, Praktiknya, harus diakui secara jujur terjadi ekspoitasi atas Politik identitas. Dapat dikatakan "Pseudo politik identitas identitas" yakni kepura-puraan atau palsu manakala Ki Sunda sebagai local genius tidak di implentasikan sebagai subjek tindakannya, sebagai pribadi yang berpijak sepenuhnya pada nilai-nilai ke-Jawa Baratan atau ke-Sundaan, yang dituangkan dalam ide, gagasan, serta kebijakan dengan dasar merasakan, mencintai keIndonesiannya sendiri. Serta bagaimana keSundaan dalam ruang politik tidak lagi dijadikan landasan hidup, politik identitas yang seharusnya dipelihara dan di implementasikan hanya di eksploitasi untuk kepentingan pragmantis.(Slamet, 2018:237).

Selain munculnya Komunikasi Politik yang dilakukan Calon Gubernur, namu hal yang mencuat juga dalam pemilihan Gubernur Jawa Barat, terdpat kampanye hitam yang dilakukan orang- 
orang yang tidak bertangung Jawab, sehingga kontestasi pemilihan Gubernur di Jawa Barat tahun 2018 pun menjadi ajang untuk menebar kebencian sesama insan manusia, memperdebatkan ayat kitab suci, serta dengan mudahnya meng"kafir'kan orang yang tidak seiman atapun berbeda pandangan politiknya. Misalnya, Ridwan Kamil (RK) kerap kali di tempa isu-isu yang tidak sedap misalnya saja penganut Syiah, selang beberapa hari ketika dideklarasikan oleh partai NasDem, Pendukung LGBT, dituduh membela pendukung Ahok karena aksi menyalakan 1000 lilin oleh pendukung Ahok di Bandung ${ }^{1}$.

Menurut Muhtadi, (2008:199-205) Reformasi politik yang terus bergulir mengikuti arus tuntutan demokratisasi di semua level kekuasaan pada akhirnya menyentuh wilayah pemerintahan lokal. Pemilihan presiden dan wakil presiden yang dilaksanaka secara langsung oleh rakyat terus bergulir diikuti oleh mekanisme pemilihan kepala daerah, baik gubernur maupun bupati dan walikota, yang juga dilaksanakan secara langsung oleh rakyat. Konsekuensinya, komunikasi politik semakin menemukan lahannya yang semakin subur, meskipun dalam banyak hal

\footnotetext{
${ }^{1}$ https://tirto.id/serangan-serangan-kepadaridwan-kamil-coNv
}

masih berlangsung konvensional. Pesanpesan politik mulai menyentuh tema-tema lokal sesuai dengan potensi dan masalah yang dihadapi masing-masing daerah. Seolah-olah ada kekuatan yang menggerakan aspirasi tersebut setelah terkubur dalam tempo yang cukup lama. (Muhtadi, 2008:199)

Dalam proses politik lokal yang terjadi hampir di semua daerah di Indonesia, masing-masing provinsi atau kabupaten/kota mulai memperlihatkan corak polarisasi kekuatan politik yang sekaligus menjadi karekteristik kelompok sosial yang ada. Yang menarik dari proses sosial-politik seperti itu, polarisasi tidak lagi bergantung pada model yang terjadi di tingkat pusat, tetapi lebih didasarkan pada kepentingan lokal atas dasar kalkulasi pragmatis yang lebih menguntungkan.

Menurut Kumolo, Tjahjo. 2017:79 (dalam bukunya Nawa Cita untuk kesahteraan rakyat) Pilkada kini lebih menarik dibincangkan banyak orang, khususnya sejak diselenggarakan secara langsung. Perbincangan yang dimaksud adalah tentang hal ihwal calon kepala daerah dan wakilnya. Lebih jauh, sinyalemen sementara, masyarakat mulai meyakini hubungan kepemimpinan daerah terhadap perikehidupan mereka sendiri dari kepala 
daerah yang dipilih. Ini mengiindikasikan, di satu sisi, dinamika demokrasi lokal memberi sinyal positif bahwa masyarakat makin dewassa berpolitik walaupun yang menjadi perhatian dalam sejarahnya adalah janji atau program-program calon kepala daerah dan wakil kepala daerah.

Maraknya politik identitas dengan penggunaan sentimen agama yang terjadi pada Pilkada DKI Jakarta 2017 lalu, mengingatkan bahwa agama masih menjadi komoditas politik yang paling kuat. Preferensi politik yang danut karena kesamaan suku atau agama. Ketika politisasi agama itu dimunculkan dalam kontestasi Pilkada menjadi sangat berbahaya, sebab akan mengekslusi keyakinan yang lain. Begitupun dengan propaganda politik dan kampanye hitam yang terjadi di ruang media sosial menjadikan Pilkada DKI Jakarta begitu rumit.

Jika ada adigium yang mengatakan bahwa "perbedaan itu indah", lantas mengapa perbedaan yang ada malah dijadikan alat untuk memecah belah bangsa, bukannya menyatukan dan memperkuat bangsa. Menjadi persoalan ketika hiruk pikuk Pilkada DKI Jakarta menjalar ke kotakota lainnya. Terlebih lagi Jawa Barat yang akan melaksanakan Pemilihan Gubernur di tahun 2018 yang secara geografis Jawa
Barat dekat dengan DKI Jakarta. Jika melihat data survei, dikatakan bahwa Jawa Barat merupakan wilayah dengan "zona merah" mengenai SARA. Jikalau politik identitas dihidupkan seperti pada perhelatan Pilkada DKI Jakarta dengan preferensi politik yang dianut hanya sebatas suku dan agama yang menjadi komoditas politiknya tidak menutup kemungkinan dapat terluang kembali. Namun, jika itu sampai terjadi di Jawa Barat dengan masyarakat yang beraneka ragam maka cost yang dibayar terlalu mahal.

Menyoal identitas politik yang menyentuh basis agama, Deddy Mizwar yang dikonstruksi oleh pemilih di Jawa Barat, merupakan sosok yang melekat akan symbol-simbol agama yang merupakan identitas politiknya, itu terbukti dalam wawancara yangdilakukan peneliti dengan Deddy Mizwar, "iya kan itu anggapan masyarakat, kalo saya biasa saja, karena memang proses hidup saya yang harus berbuat baik, dan Islam itu mengajarkan itu, belum lagi saya sebelum terjun didunia politik sudah punya investasi social, dengan bermain filem dan sinetron dan ahir-ahir ini saying berperan sebagai tokoh yang memegang teguh prinsip keIslaman, sehingga mungkin itu menjadi melkekat 
pada diri saya" (wawancara dengan Deddy

Mizwar, 27 Januari 2018)

Beberapa provinsi dan kabupaten/kota yang telah menyelenggarakan pemilihan kepala daerah secara langsung, hampir selalu menyisakan agenda masalah yang tidak sederhana. Fenomenanya hampir sama. Masih relatif rendahnya kesiapan sebagian elit dan massa untuk menjadi pemenang ataupun "korban" dalam proses tersebut. Kondisi seperti ini, salah satunya, diakibatkan oleh karena tingginya biaya politik yang menjadi beban setiap calon. Belum lagi adanya faktor lain yang sering dapat memperkeruh iklim sosial setempat, seperti munculnya berbagai isu yang mensinyalir adanya kecurangan dalam proses yang dilaluinya. Isu-isu seperti ini sangat mudah mempengaruhi massa karena pada dasarnya secara umum mereka masih memiliki ikatan-ikatan kohesifitas sosial yang sangat dekat. (Muhtadi, 2008: 202)

Ketika kita sepakat memakai konsep demokrasi, paling tidak ada dua hal yang mesti diingat. Pertama, proposional ketika melakukan manifestasi demokrasi yang eksesnya adalah mencerdaskan. Kedua, rasional ketika memilih dan melihat objek politik bukan sebatas di mobilisasi. Maka, mencermati hal tersebut diperlukan komunikasi politik yang baik, dari intitusi politik, partai politik, aktor politik bahkan sampai institusi kampus sekalipun. Dalam kajian komunikasi politik, yang mana komunikasi politik merupakan perlombaan memberikan informasi politik melalui political education, dan kemudian masyarakat harus learning about politic. Ketika kedua hal tersebut dilakukan maka yang terjadi adalah orietasi politik masyarakat akan terbentuk. Bagaimana masyarakat memilih bakal calon yang dapat memimpin daerahnya didasarkan pada prospective policy choices. Sehingga, tidak mencederai atau menjual belikan politik identitas untuk kepentingan elit. Tapi memang perjuangan politik identittas itu benar-benar untuk memperjuangkan basic need dari masing-masing suku atau agama.

Paling tidak dalam kajian komunikasi politik siapa yang mampu menyamaratakan karakter dengan pemilihnya ia akan memenagkan kontestasi tersebut. Jawa Barat terdapat 27 Kabupaten/Kota yang mempunyai karakteristik yang berbeda. Secara geografis dan demografis di Jawa Barat terbagi pada ruang pegunungan dan pesisir, kemudian membagi kedalam segmentasi pemilih dalam kontestasi. menghasilkan; pegunungan santri, pegunungan nasionalis, dan pesisir santri pesisir nasionalis 
menjadikannya suatu ruh untuk prospective policy choice. Tidak mungkin kualitas pemimpin hanya dilihat secara survei, dengan menggunakan logika institusi penyelenggara pemilu ataupun sisi partisipasi politik menurut KPUD.

Dalam dinamika politik lokal identitas politik menjadi hal yang sentral dalam ruang Jawa Barat Identitas politik bagi aktor politik dirasa memiliki peran yang sangat penting bagi pembentukan citra aktor politik. Identitas Politik yang dilakukan oleh aktor politik (Gubernur/wakil Gubernur) bisa bermacam-macam. Mulai dari berbentuk verbal maupun non verbal. Melalui komunikasi verbal (verbal communication) dimulai dari yang sederhana misalnya, mengucap salam kemudian disetai dengan sampurasun. Dalam ruang politik di Tatar Sunda komunikasi verbal tidak kalah pentingnya dengan bahasa non-verbal. Pada persfektif komunikasi politik bahasa adalah permainan kata-kata, bahasa bukan hanya mampu mencerminkan realitas, tetap bahkan menciptakan suatu realitas.

Komunikasi non-verbal (non-verbal communication) misalnya identitas pakaian. Ada adigium yang menyebutkan bahwa "politik itu dari ujung rambut hingga ujung kaki”, artinya dalam politik penampilan dalam berpakaian pun mempengaruhi kedisukaan ataupun kedipercayaan aktor politik dimata masyarakat. Pakaian tidak hanya di deskripsikan sebagai penutup tubuh semata namu lebih dari itu., sama seperti yang ditampilkan Calon Wakil Gubernur Dedi Mulyadi dengan memakai pakaian khas Sunda yaitu baju Pangsi dengan warna putih dan ikat kepala. Dalam politik pakaian pun dapat dijadikan suatu identitas politik yang menjadikan suatu ciri khas dari pada politisi itu, bahkan pakaian pun dapat menunjukan sikap politik. Ambil contoh, sebagaimana pakaian yang pernah dikenakan oleh Soekarno Uniform (seragam) dan Pecinya. Peci pada jaman pergerakan nasional sebagai simbol perjuangan nasional, maka Uniform (seragam) dan peci, menjadi identitas politik dari pada Soekarno, atau Jokowi dengan baju kotak-kotaknya.

Dengan identitas tersebutlah orang akan mudah mengingat aktor politik tersebut. Maka dari itu, dalam perspektif komunikasi politik pun pakaian dapat memberikan identitas yang melahirkan citra tertentu bagi pemakainya karena pakaian merupakan bagian dari komunikasi nonverbal. Selain itu, Identitas partai yakni warna. Dalam komunikasi warna merupakan bentuk komunikasi non-verbal. Warna dapat 
pula di identikan sebagai suatu sikap politik bagi pemakainya.

\section{Simpulan}

Berdasarkan hasil penelitian yang telah dibahas mengenai komunikasi politik Calon Gubernur dan Wakil Gubernur Provinsi Jawa Barat dalam memunculkan identitas politik dalam Pemilihan Gubernur Jawa Barat tahun 2018 dalam meyakinkan pemilih, dapat disimpulkan beberapa hal, yang pertama, pentingnya identitas politik untuk meyakinkan pemilih dalam kontestasi pemilihan Gubernur Jawa Barat tahun 2018, kedua, identitas politik yang digunakan memalui symbol-simbol politik oleh Calon Gubernur yaitu dangan retorika verbal, baik itu menghadapi konstituen secara langsung maupun di media lama maupun baru, ketiga adalah identitas politik dalam symbol non verbal, seperti baju dan ikat kepala yang kemudian menjadi kehasan dari calon, selain ketiga hal tersebut, yang ke empat, identitas politik yang memunculkan symbol-simbol agama yang melekat pada pasangan Asyik dan Pasangan Deddy Mizwar, kesemuanya merupakan identitas politik yang sering digunakan dalam Komunikikasi Politik dengan memunculkan identitas Politik dalam Pemilihan Gubernur Jawa Barat tahun 2018

\section{DAFTAR PUSTAKA}

Buku/Jurnal

Arifin, Anwar. 2011. Komunikasi

Politik Yogyakarta : Graha

Ilmu

Creswell J.W. 2014. Penelitian

Kualitatif \& Desain Riset:

Memilih diantara lima

pendekatan. Yogyakarta :

Pustaka Pelajar.

Kumolo, Tjahyo dan Tim. 2017.

Nawa Cita Untuk

Kesejahteraan Rakyat

Indonesia. Integrasi

Perencanaan

Pembangunan Nasional dan Daerah. Jakarta : PT.

Kompas Media Nusantara

Moleong, Lexy J. 2002. Metodelogi

Penelitian Kualitatif,

Bandung, PT. Remaja

Rosda Karya.

Muhtadi, Asep Saeful, 2008.

Komunikasi Politik Indonesia.

Bandung : Rosdakarya

Nimmo, Dan. 2006. Komunikasi

Politik Komunikator,

Pesan dan Media.

Bandung : PT : Remaja

Rosdakarya. 
Pawito. 2009. Komuniksasi Politik.

Yogyakarta: Jalasutra

Setyaningrum, Arie. 2005.

"Memetakan Lokasi bagi

'Politik Identitas' dalam

Wacana Politik

Poskolonial”. Jurnal

Mandatory Politik

Perlawanan . Edisi 2/

Tahun 2/ 2005..

Slamet, Adiyana dan Dadang R

Hidayat. 2018. Political

Communication Chairman

Of West Java. Atlantis

Press
Parliament : Political Identity Of Sundanese Woman

As Political Symbols

Widayanti, Titik. 2009. Politik Subalter: Pergulatan Identitas Waria. Yogyakarta : UGM.

\section{Sumber Lain}

Undang-Undang No.8 Tahun 2015

https://tirto.id/serangan-serangan-

kepada-ridwan-kamil-coNv 